\title{
Trust and Ethics in the Social Network of Oil Palm Traders: Lessons from Indonesia
}

\author{
Yusuf Hidayat $^{1 *}$ Rahmat Nur $^{1}$ \\ ${ }^{1}$ Anthropology Sociology Education Study Program, Faculty of Teacher Training and Education, Lambung Mangkurat \\ University, Indonesia \\ ${ }^{*}$ Corresponding author.Email: yusuf.hidayat@ulm.ac.id
}

\begin{abstract}
Oil palm trade from independent oil palm farmers in Barito Kuala Regency, Kalimantan is carried out in a palm oil trading chain and involves a social network of oil palm traders. However, unlike most networks social are relatively established, social networks in the palm oil trade are loose and negotiated. This study aims to: first, describe the form of social networks in oil palm trading. Second, it describes efforts to establish and maintain networks social in the oil palm trade. This study uses qualitative research methods to gain a deep understanding of the social networks of oil palm traders. This research was conducted in the village of Sidomulyo, Wanaraya sub-district Barito Kuala District, South Kalimantan province. Informants as sources of information were selected using a purposive sampling technique. Data mining was carried out by observation, in-depth (ininterviews depth interviews) with selected informants, and daily notes. The research results were analyzed by phenomenological analysis. This study found: first, the form of social networks in oil palm traders consists of two forms of social networks, namely the social network of negotiating interests in the relationship that is built between vendors SPK and middlemen and contractual emotional social networks between middlemen and oil palm farmers. Secondly, efforts to maintain social networks are carried out in a number of ways: (1) Negotiating interests for social networks are carried out by maintaining trust through timely payment and delivery of goods and willingness to act as a vendor agent as a concession to the vendor's willingness to deposit a middleman. (2) the contractual emotional network is carried out with the middlemen's willingness to lend funds for plantation management to farmers and the willingness of farmers to sell their oil palm to middlemen as a form of gratitude and "ewuh pakewuh" ethics for their loans.
\end{abstract}

Keywords: Social networks, beliefs, ethics, oil palm traders.

\section{INTRODUCTION}

Oil palm is a leading commodity for Indonesia in international trade. The development of Indonesia's fastgrowing palm oil industry has attracted the attention of the world community, especially the world's major vegetable oil producers. Indonesia has become the world's largest producer of palm oil since 2006. In 2016, Indonesia succeeded in surpassing Malaysia. Indonesia's CPO production share has reached $53.4 \%$ of the world's total CPO, while Malaysia has a $32 \%$ share. Likewise in the global vegetable oil market, palm oil has also managed to outperform soybean oil since 2004. In 2004, total CPO production reached 33.6 million tons, while soybean oil was 32.4 million tons. In 2016, the share of world CPO production reached $40 \%$ of the world's main vegetable products, while soybean oil had a $33.18 \%$ share [1].

Palm oil has a strategic role because, among other things, palm oil is the main raw material for cooking oil so that a continuous supply helps maintain the stability of cooking oil prices. This is important because cooking oil is one of the nine basic needs of the community, so the price must be affordable for all levels of society. In addition, oil palm as one of the commodity's main non-oil and gas agricultural, palm oil has good prospects as a source of foreign exchange and tax revenue. The process of production and processing is able to create job opportunities and at the same time improve the welfare of the community [2].

The largest palm oil producer in Indonesia is a province that is on two islands namely Sumatra and Kalimantan. One of the oil palm producing areas on the island of Kalimantan is Barito Kuala Regency which is a district that has the largest peat swamp forest in South Kalimantan Province which is dominated by Galam (Melaleuca cajuput) as the main vegetation constituent of peat swamp forest. The area of oil palm plantations in Barito Kuala Regency is 72,464.2 hectares, consisting of private and community-owned oil palm plantations [3].

The management of independent palm oil by the community as the focus of this study is carried out through traditional management of oil palm plantations by increasing the quality of oil palm fruits that are of the same quality as company-owned palm fruits by maintaining sufficient crops so that palm oil remains fertile and has fruit high quality [4]. 
Independent oil palm plantations are known as fresh fruit bunches (FFB) farmers. Fresh fruit bunches that have been harvested are then sold to factories owned by the company's industry through middlemen. The price of each sale is determined by collectors and industrial companies. Oil palm farmers and middlemen (tengkulak) have a very close relationship with each other, farmers need traders as a place for them to sell their crops, middlemen (tengkulak) need farmers to fulfill their lives every day, various ways are done by farmers to make their income increase. a good network with traders (Collectors) brings a very big influence, their income is getting better even though the profits are sometimes not very large. The network that is built is the most important asset in maintaining the continuity of palm oil sales with all the existing limitations. Farmers will try to build a strong network of traders, this network will make it easier for farmers and traders.

Social relations that are well established over time will form a social network. Social networks are relationships that are created between many individuals in a group or between groups with other groups. Social relations are a picture or reflection of cooperation and coordination between residents which is based on active and reciprocal social ties [5].

The Networking approach social sees the market as a structure of relationships between several market actors such as companies, competitors, suppliers, distributors, customers, buyers, and so on. all these actors form a complex network of relationships involving cultural capital and capital social. the market is currently seen not only because there are demand and supply but more than that is the complexity of the network of market actors who use various kinds of socio-cultural energy such as trust, clintization, ethnicity, regions, and clans.

The oil palm trading system between farmers, collectors, and companies often creates a dynamic phenomenon when it is associated with the price of oil palm on the oil palm industry market in Indonesia. The problem raised here is How to Utilize the Social Network of Palm Oil Traders in Sidomulyo Village, Wanaraya District, Barito Kuala Regency, South Kalimantan. This study aims to: First, describe the form of social networks in the oil palm tradein Village Sidomulyo, Wanaraya sub-district, Barito Kuala Regency, South Kalimantan.

Second, describing the efforts to establish and maintain networks social in the oil palm trade-in Village Sidomulyo, Wanaraya sub-district, Barito Kuala District, South Kalimantan.

\subsection{Related Work The}

study of networks social has been done by many scientists social and various opinions have been conveyed about the definition of networks social what has been done $[6,7$, $8,9,10,11,12]$.

Barnes, which defines a social network as a system of social relationships between definitive parts of the unit [6]. Furthermore, Powell and Smith [11] define networks as social as a set of relationships or bonds between actors (both individuals and organizations). The bonds between actors have both content (a form of relationship) and form (strength of relationship). The content of ties consists of information, solidarity, sharing noble membership and various forms of social relations that can be categorized as social ties. So organizations are embedded in overlapping networks - sources of exchange networks, information networks [11].

Scientists Although social have the same attention to networks social, they are different in analyzing them. One of them is Schenk (1994) who argues that one of the fundamental problems of network analysis is the specification and operationalization of social relations of interest and at the level of analysis at which these relationships can be realized. Starting from the nation-state, regional, multinational interest groups. The organization, company directors, individuals, families, groups, or couples as the unit of analysis and at the level of the structure of the relationship will be analyzed from the perspective of a rational or positional [9]. (Schenk: 1983).

Another view of aspects of network analysis social is the view of Wellman (1983) who does not pay attention to the level of analysis problem but is more directed to the 'bonding' aspect, namely ties between and among actors who are "not strongly bound and does not fully meet the requirements of the group [8]. In line with Wellman (1983), Granovetter (1985) shows that the main principle of social network analysis is based on the idea that economic activity is socially rooted and rooted in social relations. Social networks are a series of relational relationships or interrelationships between elements in a system.

Mitchell [13] emphasizes that networks social as an analytical concept are not only seen from a series of relational relationships but also how the characteristics social of existing relational relationships can be used to interpret the actions social of the people involved in them. To interpret the actions social of members involved in social networks, Burt (1982) uses an approach cultural social networks. This approach assumes that the involvement of individuals in a social network is not only one person but many people. The nature of the relationships that exist in individuals may exist in other individuals, such as beliefs, perceptions, attitudes that are carried out by individuals in other individuals. The study of Burt and Burzynski (2017) shows how the social networks of Chinese businessmen in Western countries in Eastern countries have in common, namely adhering to values cultural Chinese Known as "guanxi".

Burt (1982) explains that cultural analysis in social networks focusing on a part of the entire network social called the reticulum, which is limited to the analysis of the relationship between individuals who are directly related to actors certain economic(egos). The analysis of culture network in a social system is called the total network, which consists of the reticulum- the reticulum as a personal network or clicks in the social system.

Monge [14] put forward the reticulum as a personal social network built on individual egocentric interests and initiatives. Personal networks that are used continuously and repeatedly will form a steady, permanent, and the sustainable pattern called a click. Monge revealed that 
personal network analysis or analysis click takes place through the relational relationship between star, liaison, and members to fulfill his ego.

The study of social networks in this study also uses a cultural approach by examining the form of relations between actors involved in social networks as actors that cannot be separated from their culture who adapt to the interests of the sustainability of their trading business.

\subsection{Our Contribution}

This research is useful in practical terms in opening the trade chains of oil palm and shows several forms of helplessness among farmers so that it can be input for policymakers to provide. Various stimulus packages to develop independent oil palm plantations.

This research is also useful theoretically in studies of economic sociology, especially those related to social network theory. This review shows that "clicks" are awakening. In a social network, it can always be negotiated according to the interests and development of the resources of each actor and the values that serve as their binding can always be interpreted according to their situation and social background.

\section{METHODOLOGY}

This study uses qualitative methods to gain a deep understanding of social networks and dynamics in the oil palm trade. With this method, phenomena are examined in their natural context, understood, or interpreted in terms of the meaning attached to humans (researchers) to them [15]. The phenomena studied by this method are also directed at a detailed examination of problems that arise naturally in social life [16]. Therefore, this study examines the social network of oil palm traders in detail and in-depth so as to obtain a deep understanding of the form of social networks and the use of these social networks by the actors involved in them. This research was conducted in Sidomulyo village, Wanaraya district, Barito Kuala Regency, South Kalimantan Province. The subjects of this research are traders involved in the palm oil trade, from collectors, SKP owners to palm oil processing companies to $\mathrm{CPO}$ as raw materials for products using palm oil.

There are several activities carried out by researchers for the purpose of collecting data. First, an observation by looking directly at the trading activities of oil palm traders, how to greet the traders, the physical characteristics of the traders, and various other behaviors related to oil palm trading activities at the locations of palm oil trading transactions. Second, in-depth (interviews in-depth interview) using unstructured interviews with selected informants. Third, the diary is an important source of data in the research used in this study.

Data analysis starts with the interview transcript obtained from the field. The interview transcript is then given marginal notes in the form of the theme being studied, the sequence of events as well as a conceptual explanation of the phrases written to facilitate analysis. Interview transcripts from several informants were then classified based on themes in accordance with the research objectives.
Classified data is then narrated so that it can describe phenomena in accordance with data obtained from the field and produce various research findings. The findings of this study are then discussed with previous theories related to the research theme.

\section{FINDINGS}

\section{1 "Click" in the social network trading palm}

Palm individual Farmers oil spread in Barito Kuala Regency, South Kalimantan, known as palm growers of fresh fruit bunches (FFB). They are not part of the oil palm companies that develop oil palm plantations, both nucleus estates, and plasma estates. Independent farmers generally build independent businesses because they do not want to join large companies and do not participate in the plasma plantation scheme for various reasons. They prefer to manage their land with their own business in the hope that they will get their own income from the land they manage. Palm oil produced by independent farmers will then be sold to palm oil processing companies. Palm oil marketing distribution chains from oil palm growers' estates are bought by middlemen and sold to palm oil processing factories through vendors who have SPK as suppliers of palm oil to palm oil companies processing. The distribution channels of oil palm above are built into several relationships between traders vertical and become a social network in the oil palm trade.

The social network that is built in the oil palm trade is built due to mutual interests between one level of trader and another trader. The interests exchanged between the actors in the oil palm trade are the availability of raw materials for the traders above and the financial guarantees for the traders below. They exchange interests to stabilize the relationships they build and in the long run, have formed a "click".

The "clique" built by vendors and middlemen was built to secure the interests of each member of the clique in dominating the oil palm market. Vendors as the owner of SPK (Work Agreement) as a supplier of palm oil are targeted by the company to supply a certain amount of palm oil CV MBS (Maju Bersama Sejahtera) For example, targeted by the company PT Palmina to supply palm oil as much as 200 tons per month. They must meet the supply needs in various ways including maintaining good relations with the skipper as a direct trader who deals with farmers. Likewise, with the skipper, they will maintain good relations with the SPK owner vendors who help a lot in providing the capital they need to provide finance as a binder to oil palm farmers. How vendors, middlemen, and farmers relate will be described in the following article.

\subsubsection{Relationships of vendors with middlemen}

Relationships with middlemen are interwoven in the relationship of symbiosis mutualism. Vendors need middlemen to ensure that the supply capacity of palm oil shipments to the company can be met. Vendors are targeting to ensure that middlemen send goods to the company using their SPK, not using the SPK of other vendors. To ensure this, they make middlemen their agents in the midst of the 
oil palm farmers and get as much palm oil as possible from the oil palm farmers to meet their supply targets.

Vendors need middlemen so they want to sell oil palm to them, not to their competitors. To get priority from middlemen, vendors usually give middlemen a deposit as collateral for their supply. With deposit money, the vendors take care to prevent the middlemen from selling their oil palm using their SPK.

On the other hand, middlemen need money to finance the costs of oil palm farmers. Deposit money provided by vendors they use to help finance the farmers.

This relationship is so strong, making the vendors and middlemen establish cooperation in a social network because of the "click" of the common interests in controlling the palm oil market of their competitors. Vendors become donors to middlemen to finance oil palm purchase transactions and middlemen become agents of vendors to obtain oil palm from farmers.

Vendors and middlemen relationships are developed because of mutual interests that need each other. However, the relationship that is built between them is not more than the same interests so there is no very strong emotional connection. Their relations are tentative and negotiating so they are very vulnerable when emerge new competitors. In some cases, the middlemen may turn to other vendors who have greater capital strength who can provide greater financial assistance to the middlemen.

\subsubsection{Middlemen (Tengkulak) Relations with farmers}

Oil palm farmers, when they do not produce FFB (fresh fruit bunches) they still do not produce a profit. Therefore, they must cover all daily life and palm oil management needs of third parties. They borrow funds from middlemen with the consequence of fulfilling their obligation to sell oil palm plantation products to them. They were forced to borrow from middlemen because they could not access loan funds to banking institutions because of their limitations in fulfilling the requirements administrative proposed by the banks.

Apart from the problem of financing, the dependence of farmers on middlemen also occurs due to their lack of access to the sale of palm oil to oil palm companies as well as to vendors holding SPK. The vendors the holdingSPK usually send oil palm to oil palm companies through the transportation of oil palm trucks and this capacity can only be done by middlemen as collectors of oil palm from oil palm farmers. Farmers cannot sell palm oil directly to oil palm companies but through middlemen with SPKs from their respective vendors. Therefore, farmers can only sell oil palm through middlemen so that the level of dependence of farmers on middlemen becomes higher.

On the other hand, the position of middlemen as agents of vendors makes them traders who get a target in fulfilling the production capacity of the vendors. To meet these targets, it is in their interest to secure supply guarantees from oil palm farmers. To get this guarantee, they build relationships with oil palm farmers. They help financially to finance the management of oil palm plantations. They fund plantation management, maintenance of oil palm trees, fertilizers, and others.

\subsection{Efforts Strengthen Social Netwoks}

In economic behavior, the concept of trust is inherent. The new approach to economic sociology or often also referred to as the "attachment" approach proposes a more dynamic view, namely that trust does not emerge instantaneously but rises from the interpersonal relations process of actors who have long been involved in behavior joint economic. Trust is not a new thing (it doesn't change), but on the contrary, it is continually interpreted and valued by the actors involved in the relationship of behavior economic.

"Trust" in the oil palm trader network is very firmly held by all layers of oil palm traders, both by vendors and middlemen. Each trader has his own way of maintaining trust in the oil palm trade.

\subsubsection{SPK owne vendors}

For the vendors, they also very much hold on to their trust. In the palm oil trader network chain, the vendor's position is between (intermediaries) between palm oil processing companies and middlemen as palm oil suppliers from farmers. The trust built by them is a trust from two directions, namely the trust of the company and the trust of the middlemen. First, the trust of the company is built thanks to their accuracy in supplying palm oil commodities to the company. They can reach the target according to the agreement with the company. Their suitability to achieve the target will facilitate the company in meeting its production targets.

Second, trust from middlemen. The belief in question is the belief that he as a trader who is above the trader below him can afford to pay them. To build this trust, the traders who act as buyers of palm oil from the traders under them are always paying palm oil on time. Because if they don't pay on time, then people's trust in them will be destroyed because they are deemed not to have enough capital to buy their palm oil.

\subsubsection{Middlemenholding}

The good relationship between middlemen and oil palm farmers and with the vendors can be developed in the interaction patterns they form in their daily lives and by maintaining a good reputation. For the middlemen, they also really hold on to it. Their position is among the oil palm farmers and under the SPK owner vendors, so they must establish good relations with the other two actors in the oil palm trade. With oil palm farmers, they must build good relationships and always maintain their trust. The belief in question is the belief that he as a middleman who buys oil palm from oil palm farmers can afford to pay for their oil palms. To build this trust, the middlemen who act as buyers of oil palm from oil palm farmers are always paying for oil palm on time. Because if they don't pay on time, the farmers' trust in them will be destroyed because they are deemed not to have enough capital to buy palm oil. 


\section{DISCUSSION}

In the oil palm trading network, the middlemen who are in a position under the vendors who own the SPK will also function as supporting their businesses to ensure the fulfillment of palm oil supply to palm oil processing companies. They must always maintain the trust of the SPK owner vendor. To earn this trust, they will always meet their palm oil sales target in accordance with their agreement. The middlemen always hold these two forms of belief, in the hope that they will gain progress in the oil palm trade. Once they injure their 'trust' then their good image in front of their partners will be destroyed and of course, will narrow their space in the palm oil trade. And if released with their partners, they must build relationships again with other partners which of course also will result in funding that they have to spend again.

The study of the social networks of oil palm traders has the same approach as that of Burt (1984), Burt, and Burzynski (2017) who use analysis culture understanding the behavior of individuals (as entities that cannot be separated from the society and culture) involved. in social networks.

From a study of the social network of oil palm traders, it is found that there are two forms of relationships in the social network of oil palm traders, namely the negotiation of negotiating interests between vendors owning SPK with middlemen and contractual emotional relations between middlemen and oil palm farmers.

The vendor relationship between SPK owners and middlemen is formed because of the same interests, namely meeting the target of palm oil supply for vendors and certainty of payment and capital assistance for middlemen. This relationship has formed a "click" between them by making the vendor a leader in this "click". This relation is the same as the concept of "clicks" from Monge (1981). However, in contrast to Monge who saw the relationship between members of the "clique" which was relatively constant and permanent, the relationship between vendors and middlemen was tentative and negotiating.

Vendors who own SPK and middlemen will always negotiate their interests in maintaining the continuity of the "clicks" they build. This condition makes the relationships they build very fragile so that in some cases, the "clicks" they build end when the interests of one actor (especially middlemen) are not fulfilled, namely capitalization in the supply of palm oil and are very open to the emergence of new vendors have greater capital.

Unlike the relationship between SPK owner vendors and relatively fragile middlemen, the middleman and farmer relations are strong relationships because they have built very strong emotional relationships and can be categorized as contractual emotional relationships. This relationship is said to be an emotional relationship because the relationship they built was based on emotion because of the farmers' gratitude to the middlemen for the loans they received in financing their plantations. And it is said to be a contractual relationship because the relationship they build is limited to a contract that they agree together even though it is not in writing. The unwritten contract between them is insofar as both parties heed "ethics" in their relationship.
The oil palm farmers are actually in a weak position in relation to the middlemen because they are financially very dependent on the middlemen. Farmers often take cash receipts from middlemen to meet their daily needs when the oil palm is still in the process of not producing fruit. They will ask for help from the middlemen in meeting the needs of purchasing fertilizers for palm oil plants and fulfilling their daily needs. The oil palm farmers highly uphold the "ethics" of middlemen that are prioritizing the sale of their oil palms to the middlemen who have helped finance their economy when it has not yet produced. However, they also have limitations in considering their "ethics" to middlemen. They will tolerate the price from the middlemen when the price offered by the middlemen is not too far from the market price. Oil palm farmers, with the incessant information media and the many competitor's other middlemen, know the market price of oil palm and will decide to sell to other middlemen when the price is too far from the market price.

In other words, the efforts of middlemen to maintain relations with farmers by giving loans to them do not necessarily mean they can do what they want with farmers. Palm oil farmers, who are predominantly Javanese, maintain the "ethical" morality of "ewuh pakewuh" and appreciate the sacrifices made by the middlemen. However, they also have another scale, which is an appreciation of their efforts in managing their oil palm by providing a fair price, not far from the market price. If the middlemen value oil palm at a very low price, far from the market price, then they will label them as "unethical" middlemen so that they will consider it legal to violate the "ethical" morality of "ewuh pakewuh" by selling oil palm to middlemen another gives the price of oil palm at a reasonable price.

Understanding the relationship between middlemen and oil palm with the ethical concept "ewuh pakewuh" is a study of the relations of actors from a cultural perspective as done by Burt (1984) and Burt and Burt and Burzynski (2017) who discovered the concept of "guanxi" in the social networks of Chinese entrepreneurs both in the West and in the East. The concept ewuh pakewuh on middlemen and oil palm farmers based on the concept of the Java community (where the majority of residents in Sidomulyo is Javanese ethnicity)

\section{CONCLUSION}

Based on studies that have been done on social networks trader of palm found some of the following: first, the form of social networks on Palm oil traders consist of two forms of social networks, namely a social network of negotiating interests in the relationship that is built between vendors SPK owners and middlemen and contractual emotional social networks between middlemen and oil palm farmers. This relationship is very fragile because relations are built to the extent that the common interests are always negotiated between the two parties. Second, efforts to maintain social networks are carried out through several ways: (1) for social networks the interests of negotiations are carried out by maintaining trust through timely payment and delivery of goods and broker's willingness to become a 
vendor agent as a concession to the vendor's willingness to deposit a broker. (2) for contractual emotional networks carried out by the willingness of middlemen to lend funds for the management of plantations to farmers and the willingness of farmers to sell their oil palm to middlemen as a form of gratitude and ethical "ewuh pakewuh" for the loans provided. Farmers will maintain the ethics of "ewuh pakewuh" in the sale of oil palm to middlemen as long as the middlemen maintain ethics by buying oil palm at a reasonable price. If the middlemen violate the ethics, then the farmers can also violate the "ethics ewuh pakewuh"and sell palm oil to other middlemen.

Based on some of the findings above, this study suggests that to strengthen oil palm plantations as a new renewable energy source, various levels of society that contribute to oil palm development are empowered and obtain various stimulus packages to develop their capacity and capability in developing oil palm plantations.

\section{ACKNOWLEDGMENT}

This work was funded by the Teacher Training and Education Faculty of Lambung Mangkurat University.

\section{REFERENCES}

[1] United States Department of Agriculture (USDA), Index Mundi, Agricultural Statistic. Washington DC: USDA, 2016.

[2] A. Syahza, "Kelapa Sawit dan Dampaknya Terhadap Percepatan Ekonomi Pedesaan di Riua," Universitas Riau, 2007.

[3] "Dinass Hutbun Barito Kuala," 2014.

[4] M. Noor, Pertanian Lahan Gambut Potensi dan Kendala. Yogyakarta: Kanisius, 2001.

[5] Damsar, Sosiologi Ekonomi. Jakarta: Raja Grafindo Persada, 2002.

[6] J. A. Barnes, "Class and Committees in a Norwegian Island Parish," Hum. Relations, vol. 7, no. 1, pp. 39-58, 1954, doi: $10.1177 / 001872675400700102$.

[7] M. Granovetter, "Economic Institutions as Social Constructions: A Framework for Analysis," Acta Sociol., vol. 35, no. 1, pp. 3-11, 1992, doi: 10.1177/000169939203500101.

[8] B. Wellman, "Network Analysis: Some Basic Principles," Sociological Theory, vol. 1. p. 155, 1983, doi: 10.2307/202050.

[9] T. Menkhoff, Towards an understanding of Chinese entrepreneurship in Southeast Asia: small trading firms in Singapore. Universität Bielefeld, 1990.

[10] R. S. Burt, Toward A Structural Theory of Action: Network Models of Social Structure, Perception, and Action. New York: Academic Press, 1982.

[11] L. Smith-Doerr and W. W. Powell, "Networks and economic life," Handb. Econ. Sociol., pp. 379-402, 1994.
[12] R. S. Burt and K. Burzynska, "Chinese Entrepreneurs, Social Networks, and Guanxi," Manag. Organ. Rev., vol. 13, no. 2, pp. 221-260, 2017, doi: 10.1017/mor.2017.6.

[13] M. Wijaya, Ekonomi Komersial Ganda: Perkembangan Kompleksitas Jaringan Sosial Ekonomi Perbatikan di Surakarta. Surakarta: Lembaga Pengembangan Pendidikan (LPP) dan UNS (Sebelas Maret University), 2010.

[14] P. R. Monge, "The Network Level of Analysis," in Handbook of Communication Science, 1987, pp. 239-270.

[15] Y. S. Denzin, Norman K. dan Lincoln, Handbook of Qualitative Research. Yogyakarta: Pustaka Pelajar, 2009.

[16] W. L. Neuman, Metodologi Penelitian Sosial: Pendekatan Kualitatif dan Kuantitatif. Jakarta: Indeks, 2013. 